\title{
Research on Public English Teaching Reform in Applied-Type Undergraduate University Based on Professional Ability Training
}

\author{
Ying Huang, Huijun Fu \\ Baoding University, Baoding, China \\ Email: yinghebtu@163.com
}

How to cite this paper: Huang, Y., \& Fu, H. J. (2020). Research on Public English Teaching Reform in Applied-Type Undergraduate University Based on Professional Ability Training. Creative Education, 11, 2233-2239.

https://doi.org/10.4236/ce.2020.1111163

Received: October 6, 2020

Accepted: November 10, 2020

Published: November 13, 2020

Copyright $\odot 2020$ by author(s) and Scientific Research Publishing Inc. This work is licensed under the Creative Commons Attribution International License (CC BY 4.0).

\begin{abstract}
With the development of internationalization, the public English reform is going on in Chinese universities. By investigating the current situation of public English teaching in Baoding University based on 92 questionnaires, the study summarizes the existing problems in public English teaching in terms of teaching content, mode, practical teaching, evaluation method, and faculty team. In order to solve these problems, some reform strategies are advocated with the purpose of promoting teaching reform by improving the English related quality in professional competence.
\end{abstract}

\section{Keywords}

Applied-Type Undergraduate University, Public English Reform, Professional Competence

\section{Introduction}

As the frequency and level of world communication continue to increase, the importance of English is increasing day by day, and the degree of specialization is becoming higher and higher. In response to the development of globalization, China has begun to pay attention to the reform of English teaching. Research on the reform of public English teaching in applied undergraduate universities based on professional ability training is an important content of the current English education reform. In 2015, the Ministry of Education of China, China Development and Reform Commission, and Ministry of Finance of China collectively issued the "Guiding Opinions on Guiding Some Local Ordinary Undergraduate Universities to Transform into Applied-typed" which illustrated China will prioritize the development of applied technology universities and 
build a group of high-level applied-type universities with Chinese characteristics that directly serve regional development and industrial revitalization (Yang \& $\mathrm{Qu}, 2018)$. As a product of the popularization of higher education, applied-type undergraduate education has played a positive role in satisfying China's economic and social development, cultivating high-level applied-type talents and promoting the popularization of higher education in China (He, 2015). In 2015, Baoding University was identified by Hebei Provincial Department of Education as a pilot school of transforming into applied-type universities which put forward more requirements on cultivating applied-type talents with professional competence.

Based on the questionnaire investigation on public English teaching by teachers and students of Baoding University, this article summarizes the current existing problems in the teaching content, teaching mode, practice teaching, evaluation method, teacher ability, etc. Then it puts forward reform strategies from multiple dimensions.

\section{Literature Review}

At the beginning of the 21 st century, China clearly pointed out that "the reform of college English teaching should focus on the oral and professional application skills of the students' majors". It emphasizes the combination of college English teaching and students' majors, and reflects the instrumental nature of college English (Cai, 2010). By investigating the current problems in college English teaching that are not conducive to teaching development, Mo \& Huang (2012) innovatively propose to reduce the distinction between public English and professional English and strengthen the integration of the two. They also emphasize the importance of reading and writing practice in the reform of English teaching practice. Beside the researches on the overall level of college English reform, there still some researchers take a specific perspective to carry out related studies. Wan (2017) analyzed the current situation and existing problems of college English teaching from the perspective of linguistics, and put forward targeted reform suggestions from five aspects of teaching mode, curriculum system, teaching methods, teacher and student roles, and pre-evaluation of teaching supervision. By explaining the relevant theories, classifications and stimulating trainings of learning motivation, Sun (2017) proposed to stimulate students' learning motivation in English intensive reading classes in order to achieve expected teaching feedbacks and promote English teaching reform.

\section{Research Methodology}

\subsection{Research Instrument and Content}

In order to have a more comprehensive investigation of the current situation of public English teaching in Baoding University, this survey was conducted in the form of questionnaires. The content of the questionnaire involves teaching objectives, teaching content, teaching mode, teaching process, teaching methods, 
teaching evaluation and assessment, teaching media, teaching quality, and practical teaching, etc.

\subsection{Participants}

The subjects of this survey are two groups of people. The first category is the 13 first-line teachers of public English in the School of Foreign Language Education and International Business of Baoding University, including 12 teachers with master's degrees, 6 lecturers, 5 associate professors, and 2 professors. Altogether 13 teachers have more than 3 years of public English teaching experience and teach students from two or more different majors. They participate in all procedures of teaching and have rich experience in practical teaching which contribute to the persuasiveness of the survey results. The second category of participants is the sophomore students respectively majoring in humanities education and chemistry of Baoding University. The two majors are liberal arts and science majors with a total of 79 students (25 males and 54 females). All students have successfully completed the one-year college English course and are more familiar with classroom teaching than other grade students which makes the survey results are more convincing to some extent.

\subsection{Data Collection and Analysis}

This survey took the form of an online survey and collected 92 questionnaires, including 13 questionnaires for teachers and 79 questionnaires for students. The specific survey results are as follows in Table 1.

According to Table 1 , it is clearly revealed the overall evaluation of public English teaching quality of Baoding University is not very high with only $27.17 \%$ approval. Based on the above statistical data, mainly five aspects in teaching with lower approval (lower than 50\%) are relatively prominent than other respects:

1) Repetitive, single and non-innovative teaching content

There exists a common situation in public English teaching in applied-type universities that the same kind of teaching material, teaching method and teacher. In other words, there is no difference for different majors in terms of the teaching content. In the long run, it will lead to the poor professional adaptability and insufficient employment practicability.

2) Lack of coherent application of advanced teaching mode.

In the process of public English teaching in applied-type universities, the teacher-led teaching mode has been unable to arouse students' interest in English learning. Most teachers will consciously take students as the center and base on the needs of students' skills cultivation by serving personalized learning. However, due to the limited ability of teachers to integrate new knowledge, most teachers only periodically apply the students-centered teaching model which can arouse students' learning enthusiasm, and the traditional teaching mode is still the normal application.

3) Lack of practical teaching 
Table 1. A questionnaire of evaluation on public English teaching of Baoding University.

\begin{tabular}{|c|c|c|c|c|c|}
\hline Research content & $\begin{array}{c}\text { Strongly } \\
\text { disagree \% }\end{array}$ & $\begin{array}{l}\text { Disagree } \\
\%\end{array}$ & $\begin{array}{c}\text { Neutral } \\
\%\end{array}$ & $\begin{array}{l}\text { Agree } \\
\%\end{array}$ & $\begin{array}{l}\text { Strongly } \\
\text { agree } \%\end{array}$ \\
\hline 1) Clear teaching goals & 5.43 & 13.04 & 16.30 & 34.78 & 30.43 \\
\hline $\begin{array}{l}\text { 2) Rich teaching content, innovative } \\
\text { and suitable for professional ability } \\
\text { development }\end{array}$ & 18.48 & 34.78 & 20.65 & 18.48 & 5.43 \\
\hline $\begin{array}{l}\text { 3) Diverse and innovative teaching } \\
\text { methods }\end{array}$ & 9.78 & 20.65 & 29.35 & 17.39 & 22.83 \\
\hline $\begin{array}{l}\text { 4) Continuous application of teaching } \\
\text { model reform by keeping } \\
\text { students-centered }\end{array}$ & 30.43 & 36.96 & 9.78 & 13.04 & 9.78 \\
\hline $\begin{array}{l}\text { 5) Actively carry out practical teaching } \\
\text { and highly integrate with professional } \\
\text { ability cultivation }\end{array}$ & 33.70 & 43.48 & 9.78 & 7.61 & 5.43 \\
\hline $\begin{array}{l}\text { 6) Diversified teaching evaluation } \\
\text { with high-level application }\end{array}$ & 21.74 & 41.30 & 14.13 & 11.96 & 4.35 \\
\hline $\begin{array}{l}\text { 7) Appropriate and enough teachers' } \\
\text { competence to cultivate students' } \\
\text { professional abilities }\end{array}$ & 16.30 & 34.78 & 14.13 & 18.48 & 16.30 \\
\hline $\begin{array}{l}\text { 8) Motivated learning and good } \\
\text { feedbacks from students }\end{array}$ & 5.43 & 23.91 & 32.61 & 23.91 & 14.13 \\
\hline $\begin{array}{l}\text { 9) Diverse teaching media with high } \\
\text { utilization }\end{array}$ & 5.43 & 25.00 & 31.52 & 23.91 & 14.13 \\
\hline $\begin{array}{l}\text { 10) High teaching quality adjusting } \\
\text { to the needs of professional } \\
\text { ability training }\end{array}$ & 25.00 & 30.43 & 17.39 & 16.30 & 10.87 \\
\hline
\end{tabular}

There is a lack of practical teaching links between public English teaching and majors in applied-type undergraduate colleges. The proportion of theoretical courses is far higher than that of professional practical courses. Students are still in a closed teaching environment and passively acquire knowledge. The lack of opportunities for students to practice public English ability results in students' serious deviation from the social needs of specialization.

4) Single teaching evaluation method.

Public English teaching still takes the final written test score as the main evaluation standard and has not reformed. Most applied-type undergraduate colleges do not have applied English proficiency tests related to their majors, and cannot visually show students' practical application level of English. The teaching evaluation methods have not yet formed diversified applications. Besides, the learning procedure evaluation, practical evaluation and students' self-evaluation all need to be improved.

5) Insufficient "dual-professional" teachers.

"Dual-professional" teachers should not only have a wealth of theoretical knowledge, but also have practical experience from a specific professional perspective. Whether teachers can actively adapt to the transformation of "dual-professional" and whether the students have professional public English 
foundation to meet the requirements of enterprises are the key points in the transformation process. Most of the public English teachers in applied-type universities generally lack professional practical experience which to some extent restricts the reform of public English teaching.

\section{Strategies of Public English Teaching Reform}

The reform aims to cultivate students' professional abilities which will match the requirements of internationalization by improving the practicality of the courses, and to cultivate international application-oriented talents. Having the mission of cultivating applied talents and serving local economic and social development, applied-type undergraduate universities are required a higher degree of connection between teaching and students' professional abilities. This part of the article focuses on Strategies of Public English Teaching Reform

\subsection{Implementing the Teaching Materials Co-Construction}

Teaching Materials co-construction means combining professional characteristics and job requirements. The editors and writers should reasonably choose the content and determine the level of English textbooks which ought to appropriately integrate professional English and general English. For example, the teaching content may incorporate job materials, equipment manuals, work procedures, commentary and other materials closely related to the job, so as to improve students' English application ability and comprehensive professional quality. It is also available to absorb some advanced foreign language teaching materials for vocational education. By combining the experience and the actual situation of China, the innovative and practical teaching materials can be co-constructed with Chinese characteristics which will focus on the cultivation of vocational ability.

\subsection{Reforming the Teaching Mode}

The reform of teaching modes can be divided into three aspects, namely, the combination of on-campus teaching and off-campus practice, the combination of curriculum system and professional projects, and the combination of passive teaching and active learning.

The combination of on-campus teaching and off-campus practice means that off-campus job practice should be taken as an important part of English teaching. The training of reading, speaking, listening and writing should be strengthened so that students can use it well on the basis of learning. Through intensive off-campus practice, combined with the creation of professional simulation situation in the classroom, students can learn and use business English in the simulated situation, and improve their foreign-related business communication ability through the completion of a specific task (Guo, 2019).

The combination of curriculum system and professional projects means that English knowledge used in professional project research will be included in the curriculum system. Knowledge teaching and project training will be combined 
to expand students' horizons and improve their professional ability.

The combination of passive teaching and active learning means to fully mobilize students' enthusiasm by reforming the evaluation method as a result of which students are led to accept knowledge actively rather than passively.

\subsection{Optimizing the Evaluation Method}

Aiming to optimize the traditional evaluation method, the reformative evaluation should accomplish the combination of daily assessment and final examination, knowledge acquisition and professional ability improvement. Teaching should take daily practice performance, project performance and learning status as the important contents of daily assessment, drastically reduce the proportion of final examination, and guide students to pay more attention to daily accumulation and professional competence exercise.

In order to break the general knowledge examination which mainly centered on grammar and vocabulary, daily assessment and final examination should integrate together and focus on the assessment of professional ability. The assessment method that combines the procedural evaluation of "specialization, individualization and diversification" and summative evaluation should be adopted during the whole process of learning. On the basis of analyzing the characteristics and talent training programs of different majors, the evaluation should become more professional and personalized.

\subsection{Strengthening the Faculty Team}

Strengthening the faculty team means the construction of teaching team composed of public English teachers, professional English teachers and part-time teachers from enterprises. Based on the integrated teaching and research mechanism, the team should fully explore the cooperation of general English and professional English in the cultivation of applied-type talents. Only in this way, an internal communication mechanism could be established and jointly help to enhance students' professional competence.

\subsection{Carrying out the School-Enterprise Cooperation}

The integration of enterprises with vocational schools and universities is an important way for ordinary undergraduate colleges to transform into applied-type universities. The establishment of a school-enterprise linkage mechanism aims to combine the needs of enterprises in a targeted manner and cultivate high-quality applied talents who can be employed after graduation. Carrying out school-enterprise cooperation can include the co-construction of teaching materials, the construction of practice platform and introduction of "dual-professional" teachers. The co-construction of teaching materials refers to the participation of enterprise experts and post personnel in the construction of teaching materials to improve the matching degree between the teaching materials and the exercise of professional ability. The construction of practice platform requires the enterprises to provide a first-line practice platform for stu- 
dents which in accordance with the future employment direction of the majors and highly cultivate the students' English professional competence in real occupation and industry. The introduction of "dual-professional" teachers refers to the introduction of technical talents from industries and enterprises into colleges and universities and into the classroom. The system of "apprenticeship training" should be established into universities which would contribute to the integration of vocational employment mode and classroom teaching mode.

\section{Conclusion}

All in all, with the further development of economic globalization, China will pay more attention to the reform of English teaching in order to continuously adapt to the needs of China to participate in global economic, political, cultural, and technological exchanges. Since it is showed that there still exist some practical problems in public English teaching, the close connection and further integration with professional needs and professional competence are the direction for public English teaching reform in applied-type universities. Teaching in class should be closely combined with the needs of major development, job and social requirements. Therefore, in order to meet the needs of the society, it is significant to realize the teaching reform with the coexistence of diversity and specialty characteristics. All teaching procedures should surround the needs of professional competence together with the training objectives of various majors.

\section{Conflicts of Interest}

The authors declare no conflicts of interest regarding the publication of this paper.

\section{References}

Cai, J. G. (2010). Enlightenment of ESP Teaching in Taiwan China to the Reform of Public English Teaching in Mainland China. Foreign Language and Their Teaching, No. 6, 26-30.

Guo, J. L. (2019). Reform and Exploration of Modularized Teaching of Applied Undergraduate Public English Based on Competence. Modern Communication, No. 15, 27-28.

He, C. Q. (2015). Problems and Solutions of Applied Universities "Double Teachers" Team Building: Take Qinzhou University as an Example. The Guide of Science \& Education, No. 6, 62-63.

Mo, Q., \& Huang, W. (2012). Foreign Language Teaching Reform and Practice. Yunnan: Yunnan University Press.

Sun, J. (2017). College English Teaching and New Thinking of Reform. Beijing: China Water \& Power Press.

Wan, H. M. (2017). Research on College English Teaching from the Perspective of Linguistics. Beijing: China Textile \& Apparel Press.

Yang, X. Q., \& Qu, Z. L. (2018). Study on the Provincial Differences of the Transformation and Development of Local Universities and Colleges under the National Regulations. China Higher Education Research, No. 4, 97-102. 